\title{
Foraging behavior and at-sea distribution of White-Tailed Tropicbirds in tropical ocean
}

\author{
L. F. A. S. Campos ${ }^{a *}$, A. B. Andrade ${ }^{a}$, S. Bertrand ${ }^{b}$ and M. A. Efe $e^{a}$ \\ ${ }^{a}$ Laboratório de Bioecologia e Conservação de Aves Neotropicais - LABECAN, Instituto de Ciências Biológicas e da \\ Saúde - ICBS, Universidade Federal de Alagoas, UFAL, Av. Lourival Melo Mota, s/n, Tabuleiro dos Martins, \\ CEP 57072-900, Maceió, AL, Brazil \\ 'Institut de Recherche pour Le Développement - IRD, Centre de Recherche Halieutique Méditerranéenne et Tropicale - \\ CRHMT, UMR248MARBEC, Avenue Jean Monnet, BP 171, 34203, Sète Cedex, France \\ *e-mail: leillafasc@gmail.com
}

Received: December 15, 2016 - Accepted: February 1, 2017 - Distributed: October 31, 2018

(With 3 figures)

\begin{abstract}
We used miniaturized GPS loggers and site observations to access foraging patterns and nest behaviour of the White-tailed Tropicbird Phaethon lepturus (WTTB), an endangered species at its South Atlantic breeding colony. Dual foraging pattern was observed with alternation between long and short foraging trips. Birds responsible for nest attendance engaged in short foraging trips with mean distance from colony of $25 \pm 17 \mathrm{~km}$, total distance covered of $79 \pm 65 \mathrm{~km}$ and mean duration of $4.02 \pm 5.28$ hours. Birds flew by dawn and returned before dusk while partners were at sea for long foraging trips that ranged from four to 11 days, with mean maximum distance from colony of $105 \pm 47.48 \mathrm{~km}$. Chicks were usually left alone for hours and chick predation by Land Crab Johngartia lagostroma, egg consumption by Goniopsis cruentata and intra-specific competition are suspected to be responsible for high chick mortality rates.
\end{abstract}

Keywords: Tropicbird, GPS, dual foraging, behavior.

\section{Comportamento de forrageio e distribuição no mar do Rabo-de-palha-de-bico-laranja em oceano tropical}

\section{Resumo}

Utilizamos aparelhos de GPS miniaturizados e observações de campo para determinar padrões de forrageio e comportamento em ninho da espécie ameaçada Rabos-de-palha-de-bico-laranja Phaethon lepturus em sua colônia reprodutiva do Atlântico Sul. Padrão dual de forrageio foi observado, com alternância entre viagens longas e curtas. Aves responsáveis por cuidado parental efetuaram viagens curtas de forrageio com em média $25 \pm 17 \mathrm{~km}$ de distância da colônia, distância total percorrida média de $79 \pm 65 \mathrm{~km}$ e duração média de $4.02 \pm 5.28$ horas. As aves saíram da colônia entre o amanhecer e o entardecer, enquanto seus parceiros estavam em alto-mar em viagens longas de quatro a 11 dias de duração, com média de distância máxima da colônia de $105 \pm 47.48 \mathrm{~km}$. Filhotes foram constantemente deixados sozinhos por várias horas, e predação por Johngartia lagostroma, consumo de ovos por Goniopsis cruentata e competição intra-específica possivelmente foram responsáveis por sua morte.

Palavras-chave: Rabos-de-palha, GPS, estratégia dual de forrageio, comportamento.

\section{Introduction}

Seabirds are adapted to maximize energy intake during their life-history (Bradshaw et al., 2004). During breeding season, seabirds are central place foragers, and the spatial distribution of their foraging effort emerges from a combination of previous experience, local environmental cues and energy demand increased by the necessity to raise offspring (Baylis et al., 2008; Bonadonna et al., 2001). Considering these constraints, seabirds have to make judicious choices of where to forage successfully within a restricted time span (Bonadonna et al., 2001; Kotzerka et al., 2011).

In tropical oceans, productivity is low compared to temperate and polar waters (Longhurst and Pauly, 1987) and seabird prey distribution is patchy (Ashmole, 1971; Ballance and Pitman, 1999; Weimerskirch, 2007). Consequently, seabirds need to develop strategies for coping with this highly oligotrophic environment, such as proficient flight, plunge diving (Ballance and Pitman, 1999), 
associations to fronts and high chlorophyll concentration areas (Thiers et al., 2014), "near-obligate commensalism" (Au and Pitman, 1989) or association with sub surface predators (Ballance et al., 1997, Jaquemet et al., 2004) and dual foraging (long and short foraging trips) strategies (Congdon et al., 2005; Shoji et al., 2015)

Among tropical seabirds species, tropicbirds (order Phaethontiiformes) are characterized by their solitary feeding habits. White-Tailed Tropicbird Phaethon lepturus (Daudin, 1802) (Hereinafter "WTTB") is the species more commonly seen in association with sub-surface predators (Spear and Ainley, 2005). WTTB breed all year around suggesting that the species does not rely on a unique peak of food availability (Stonehouse, 1962; Le Corre 2001; Catry et al., 2009). During the breeding period distance to the colony seems to be the more limitant factor to foraging, before oceanographic variables such as sea surface temperature, thermocline structure or salinity (Spear and Ainley, 2005). In Brazil the species is classified as Endangered (Brasil, 2014) and reproduces on two Archipelagos that are currently suffering from exotic species' introduction and increasing anthropogenic pressure. Increasing knowledge of its foraging ecology, especially the extent of its foraging range (inside or outside the National Marine Park where the colony is located) is therefore crucial to conservation efforts.

In this study we evaluated nest site behaviour and foraging patterns of WTTB breeding at equatorial Atlantic waters using GPS loggers. Our results provide new insights on the foraging strategies of this species in highly oligotrophic tropical marine environments, and rationales for the conservation of this endangered species.

\section{Materials and Methods}

\subsection{Study site}

The study was conducted at Morro do Chapéu Island (32 $25^{\prime} 30^{\prime} \mathrm{W}, 3^{\circ} 51^{\prime} 57^{\prime}$ 'S), located at Fernando de Noronha Archipelago, northeastern Brazil (see Figure 1). The archipelago is located $345 \mathrm{~km}$ from the Cabo de São Roque, Brazilian coast (IBAMA, 1990) and has a $26 \mathrm{~km}^{2}$ area spread into 19 islets (Moreira, 2009). The area is protected by two national units, the Marine National Park (PARNAMAR) with restricted access and the Environmental Protected Area (APA), where most constructions are located and where fishing is allowed (Moreira, 2009). The mean water surface temperature ranges from $28{ }^{\circ} \mathrm{C}$ and $30{ }^{\circ} \mathrm{C}$ and the surface salinity ranges between 35.0 and $37.0 \mathrm{ppm}$ (Düing et al., 1980). The climate is tropical and the archipelago is influenced by trade winds and the Southern Equatorial Current, characterized by high salinity and low concentrations of sediments, organic matter and plankton (IBAMA, 1990). The Morro do Chapéu Island is characterized by the abundance of sedimentary rocks called "caracas", providing cavities within which WTTB nest. The presence of exotic predators, such as rats, cats and the Salvator merianae (Duméril \& Bibron, 1839) lizard as well as land-crab Johngartia lagostroma (H. Milne-Edwards, 1835 ) and Goniopsis cruentata (Latreille, 1803) is a threat to seabirds that breed in the archipelago, and most of the historical nest sites (especially in the main island) are no longer occupied by breeding seabirds due to predation and human occupation (Nunes et al., 2017).

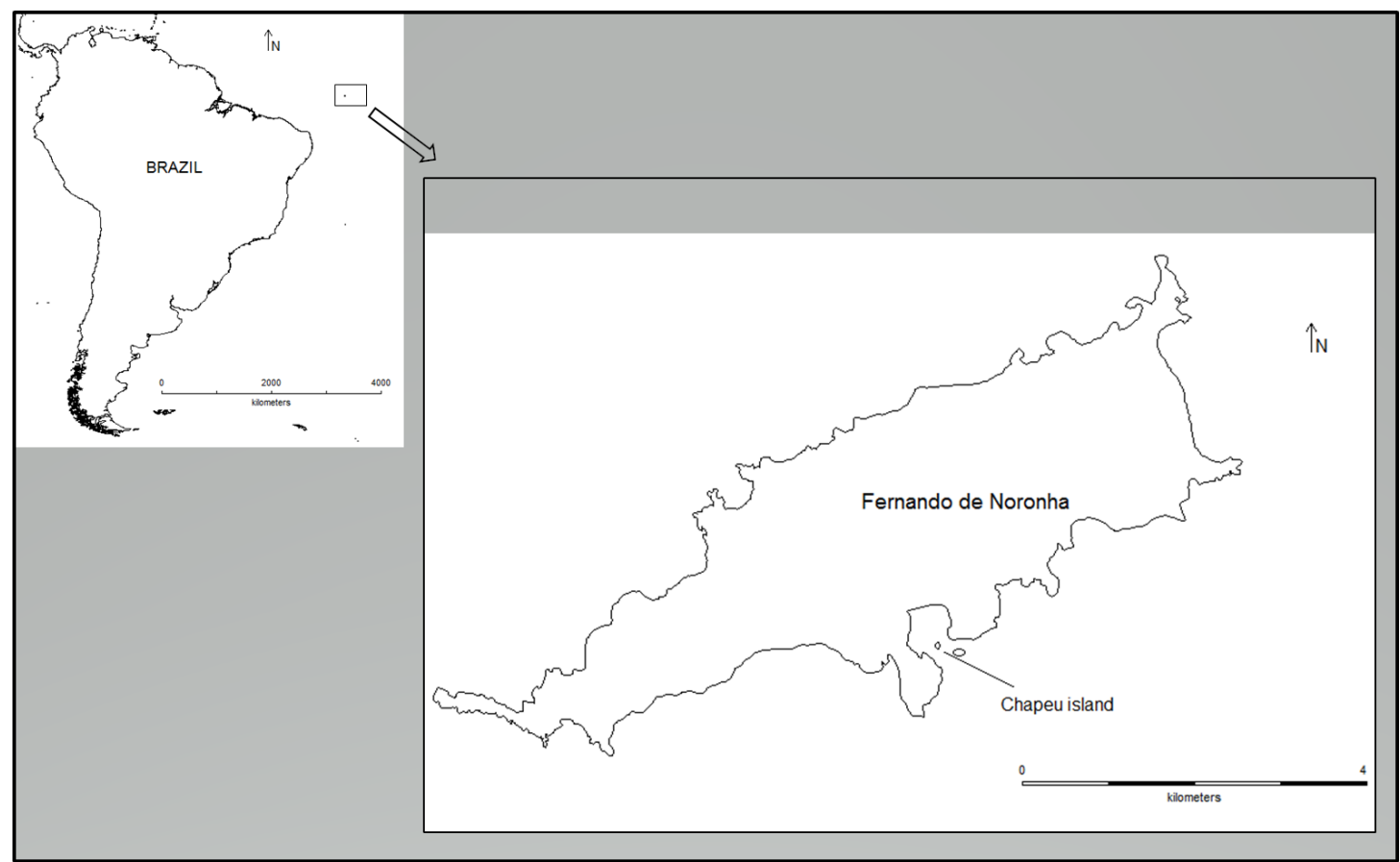

Figure 1. Study site. Source: Leal et al., 2016. 


\subsection{Sampling design and loggers}

All active nests of the islet were observed daily from August 12 to October 31 2015, except when climate conditions or high tides prohibited the access to the island. Nests with chicks younger than 5 weeks were surveyed hourly during daytime and adults rearing chicks from 1 to 3 weeks were chosen for GPS attachment. Adult birds were captured by hand and banded with stainless steel identification bands (The National Center for Bird Conservation Research - CEMAVE/ICMBio) before the attachment of the GPS logger (chicks were protected meanwhile). The devices were inserted within a heat-shrink tube for water proofing and attached at central tail feathers with TESA ${ }^{\circledR}$ tape (Wilson, 1997). Total weight of the setting was 10 to $15 \mathrm{~g}$, remaining below the $3 \%$ weight rule. All authorizations were given by CEMAVE/ICMBio (3883/1) and SISBIO (27714-6).

Birds were equipped with Gipsy 4 GPS recorders ( $5 \mathrm{~g}$, Technosmart, Italy) from August 29 to October 162015. The devices recorded date, time, longitude, latitude, instant speed ground, altitude, number of satellites and HDOP (Horizontal Dilution of Precision). The number of satellites and HDOP indicate strength on GPS accuracy, and positions with HDOP above 6 (the maximum threshold for "good" sampling) were withdrawn for the analysis.

Some birds were equipped more than once and performed several trips. Most loggers were attached at 4 a.m, since previous observations showed that animals leave the islet at dawn. The GPS recorded locations at 10,30 or 60 seconds intervals and provided a total of 26 tracks (see Figure 2), 16 of which were short and complete (those trips were performed by the partner attending the nest and had no significant loss of signal or battery exhaustion; hereinafter, those are named "short trips") and were used for statistical analysis. Six additional incomplete long trips (performed by the non - attendant partner and which duration exceeded the logger battery autonomy; hereinafter named "long trips") and four incomplete short trips are used to describe behaviour. Our constant field observation

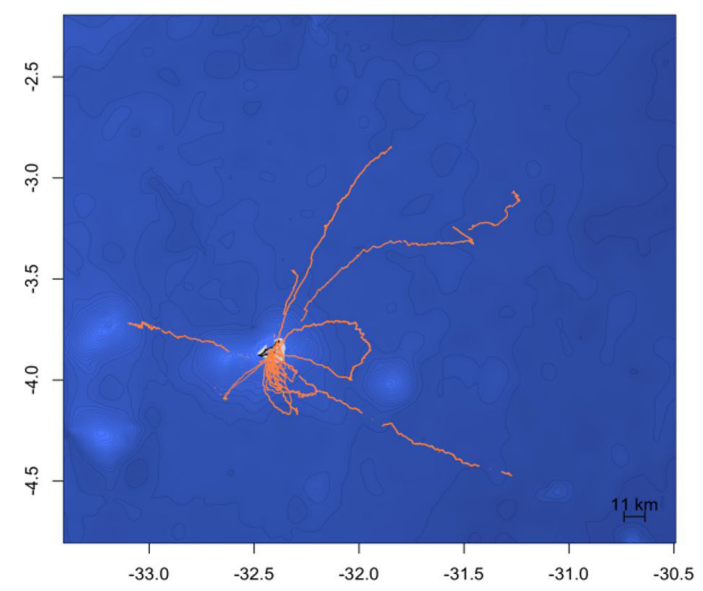

Figure 2. Foraging trips by WTTB in Fernando de Noronha. allowed estimating the duration of long foraging trips, by counting the amount of days spent away from the nest. Other trip statistics were computed directly from GPS records. Six loggers were not recovered, and one logger did not record information. Eleven trips presented errors in GPS and were not considered. For each foraging trip we computed the following indices: Maximum distance to the colony (range in $\mathrm{km}$ ), total distance travelled (length in $\mathrm{km}$ ) and trip duration (minutes).

Short and long trips (Ochi et al., 2016) were treated separately.

\section{Results}

\subsection{Foraging trips}

Eleven birds performed sixteen short and complete foraging trips, with average length of $79 \pm 65 \mathrm{~km}$, range of $25 \pm 17 \mathrm{~km}$ and duration from 38 minutes to 21.8 hours $(4.02 \pm 5.28$ hours). Long trips lasted $6.83 \pm 2.63$ days (estimation from nest observation). Maximum recorded distances from colony (probably $<<$ to the effective trip range) $105 \pm 47.48 \mathrm{~km}$ (as shown in Tables 1-2).

\subsection{Chick rearing behavior and circadian cycle}

WTTB showed a dynamic attendance behavior, where even the parent responsible for staying on the nest leaves for short foraging trips at dawn, returning after a couple of hours or even late afternoon. Four to five weeks old chicks spent most of the days alone, with one of the parents coming every other day for a few minutes or both parents coming to the nest after a long period of absence. The minimum time recorded for a nest attendance and feeding event was 34 seconds in a 6 weeks old chick.

This study showed during initial brooding and rearing period (one to two weeks old chicks) nests were attended by one partner for period up to six days. In this phase, the

Table 1. Range and duration of short and long foraging trips of WTTB in Fernando de Noronha Archipelago.

\begin{tabular}{lccc}
\hline & $\begin{array}{c}\text { Min. and } \\
\text { Max. Range } \\
(\mathbf{k m})\end{array}$ & $\begin{array}{c}\text { Mean Range } \\
(\mathbf{k m}) \\
\text { Mean+/- sd }\end{array}$ & $\begin{array}{c}\text { Duration } \\
\text { (hrs) } \\
\text { Mean+/- sd }\end{array}$ \\
\hline $\begin{array}{l}\text { Short } \\
\text { trips }\end{array}$ & $8-70 \mathrm{~km}$ & $25 \pm 17$ & $4.02 \pm 5.28$ \\
$\begin{array}{c}\text { Long } \\
\text { trips }\end{array}$ & $26.34-157 \mathrm{~km}$ & $105 \pm 47.48$ & $16.392 \pm 6312$ \\
\hline
\end{tabular}

Table 2. Trip duration and maximum distance from colony (range) on six long and incomplete foraging trips.

\begin{tabular}{ccc}
\hline Bird & Range (km) & Duration (days) \\
\hline N31003 & 76 & 6 \\
N31012 & 124 & 4 \\
N31009 & 130 & 6 \\
N34603 & 38 & 5 \\
N31043 & 26.34 & 11 \\
N24826 & 157 & 9 \\
\hline
\end{tabular}


partner coming back from a foraging trip would arrive before the attendant left to forage or a few hours later. Chicks $>15$ days were left alone for days and parents attended the nest for a few minutes or hours in each feeding event.

Departures and returns were spread throughout the day, and no bird was seen flying before dawn and after twilight. The first peak of departures was observed after sunrise (around 5:30 a.m) and most of the activity occurs during day hours (with parents' shifts, flights around the island, vocalization, departures and returns) between 9 a.m and 4 p.m mainly. Adults formed groups at departure and arrival to the colony, grouping three to eight birds.

Due to battery related issues and bird behaviour, long foraging trips' data were only partially recorded. When parental shifts occurred, the parent that was last responsible for the chick left for what we suppose to be a long foraging trip, in areas spread throughout the oceanic environment around the colony. These trips could last from four to 11 days, when the parent returned to nest only to feed chick, to stay with it for a few hours or for the next few days, during which they also performed the short trips after dawn (see Table 2).

\subsection{Dual foraging strategies}

In this study, three animals with GPS loggers performed both long and short foraging trips. The bird N31003, for instance, traveled over $326 \mathrm{~km}$ in seven hours on northwest direction, probably towards Roca's Atoll on its long foraging trip (that lasted six days). The same bird had traveled a total of $84 \mathrm{~km}$ on the previous short trip in order to feed its one week oldchick and was replaced by its partner on the morning before the beginning of the long trip (Figure 3). Another bird, the N24826, traveled $284 \mathrm{~km}$ in 26 hours in northeastern direction, on a foraging trip that lasted nine days in total. Its chick was already three weeks old, and during the early brooding period this bird performed a short foraging trip of $48 \mathrm{~km}$ in 2.2 hours towards the

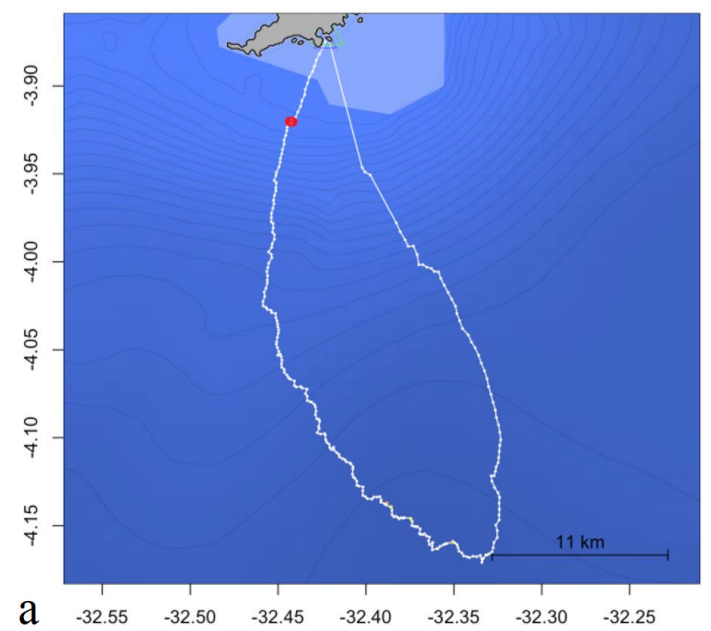

southeastern feeding site. Last, the N31043 left the nest when chick was two days old and performed the longest trip registered, of 11 days. Before battery exhaustion, the logger recorded an incomplete trip oriented towards the southeast direction, contrasting with other birds in long foraging trips. Two days after its arrival, this bird performed a short foraging trip to the southeast direction that lasted 3 hours and had a total length of $64 \mathrm{~km}$ (as shown in Table 3 ).

\subsection{Association with sub-surface predators}

Although no in situ observation was conducted in order to determine association between tropicbirds and sub-surface predators in Fernando de Noronha, the direction of most of the foraging trips (towards the southeast) is highly contrasting with the known feeding locations of the Stenella longirostris (Gray, 1828) and Stenella attenuata (Gray, 1846) dolphins that use the archipelago for resting and breeding (Silva-Júnior, 1996).

\section{Discussion}

The breeding success of colonized seabirds is strongly influenced by food availability (Hamer et al., 1993, Dearborn et al., 2001) and the vulnerability of chicks

Table 3. Comparison of traveling parameters between WTTB that performed both long and short foraging trips.

\begin{tabular}{cccc}
\hline Bird & $\begin{array}{c}\text { Type of } \\
\text { trip }\end{array}$ & $\begin{array}{c}\text { Duration } \\
\text { (hrs) }\end{array}$ & $\begin{array}{c}\text { Range } \\
\text { (km) }\end{array}$ \\
\hline N31003 & Long & 144 & 76 \\
& Short & 2.7 & 35 \\
& Short & 3.53 & 33 \\
N24826 & Long & 216 & 157 \\
& Short & 2.26 & 17 \\
N31043 & Long & 264 & 26.34 \\
& Short & 3.61 & 21 \\
\hline
\end{tabular}

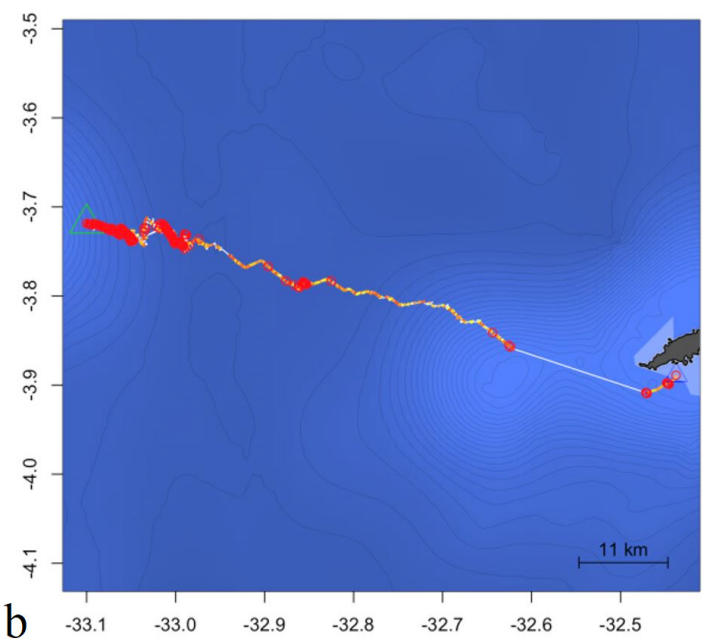

Figure 3. Foraging trips of bird N31003, with complete short trip (a) and incomplete long trip (b). Color: red dots: speed $<5 \mathrm{~km} / \mathrm{h}$ indicating bird sat on the water. 
after the first month of life can be explained by adults who spend shorter periods in the nest and longer periods involved in catching prey (Sommerfeld and Hennicke, 2010), leaving the chicks alone and potentially exposed to predators. Therefore, the speed and constancy in food transfer and the co-occurrence of pairs in nests on some occasions may increase the survival of the chicks.

Our study evidences the existence of great foraging range, a dynamic attendance behavior and dual foraging pattern, consistent with previous studies of the species in other oceans.

\subsection{Foraging trips}

Long foraging trips exceeded an average distance from colony of $105 \mathrm{~km}$, while short ones ranged $25 \mathrm{~km}$. Although this value does not represent the actual foraging range of the population (due to incomplete data on long trips) it evidences that long trips are related to a greater foraging range (Chaurand and Weimerskirch, 1994). Weimerskirch et al. (1993) and Shoji et al. (2015) found association between long foraging trips and wider foraging ranges and alternation between long and short foraging trips during chick-rearing phase, due to breeding constraints and shifts in prey availability.

\subsection{Chick rearing behavior and circadian cycle}

This paper corroborates most of the behavioral characteristics of WTTB described in Orta (1992) and observed by Schaffner (1990) at Puerto Rico. We emphasize particularly the quickness in food transfer (feeding events of less than 40 seconds) and the co-occurrence of pairs on nests in some occasions. Unfortunately, Schaffner (1990) did not provide the age of chicks when co-occurrences happened, but this study suggests that older chicks are more likely to be visited by both parents at the same time after at least two days absence of feeding events, since nine out of the 11 occasions where this behaviour happen were with chicks older than three weeks. This might be related to bimodal feeding intervals, with many short and long intervals between feeding events, according to the feast or famine character of food provisioning (Schaffner, 1990; Shoji et al., 2015).

Birds flew in circles around the colony for hours while making several landing attempts before arriving in nest. This behaviour was also documented by Schaffner (1990), as well as the lack of arrival of parents and feeding events at night. In fact, if one of the parents did not return to the nest by dusk, the chick remained alone throughout the evening. This lack of attendance might facilitate chick's' predation and egg consumption by Land Crab Johngartia lagostroma and Goniopsis cruentata, since both species are more active at night, as documented in this study and in Leal et al. (2016). Evidence suggests that chicks might also disappear from intra-specific competition, since fights between adults, adults and chicks $>30$ days and injuries were observed. This behaviour is related to high nest site fidelity and fierce fighting for previously occupied nests, as shown by Catry et al. (2009).

\subsection{Dual foraging strategies}

Previous studies show that temperate and tropical seabirds rely on dual foraging strategies to cope with energetic needs, and alternate between self-provisioning long foraging trips to a more productive areas and near-colony poorer foraging grounds, responsible for chick provisioning (Granadeiro et al., 1998; Weimerskirch, 1998; Congdon et al., 2005; McDuie et al., 2015; Shoji et al., 2015). Chaurand and Weimerskirch (1994) and Sommerfeld and Hennicke (2010) seem to confirm this observation, since birds gain substantial body mass during long foraging trips but not during short ones (but see Shoji et al., 2015).

Our observations show a bimodal pattern of foraging trips of WTTB, with the parent responsible for chick attendance leaving the colony for a short foraging trip at dawn and returning in a few hours. After the period of nest attendance they leave the colony and engage in long foraging trips, for as long as 11 days. This dual foraging pattern is similar to found on Blue petrels on Antarctic, where birds displayed both short (1-3 days) and long (5-10 days) foraging trips alternatively and no consecutive short trips (Chaurand and Weimerskirch, 1994). WTTB at Fernando de Noronha might engage into at least one short foraging trip per day while at nest, much like Wedge-tailed shearwaters from the southern Great Barrier Reef in Australia (Congdon et al., 2005) and Red-Tailed tropicbirds in Christmas Island (Sommerfeld and Hennicke, 2010).

Tropical seabirds live on a highly oligotrophic environment (Ashmole, 1971) and therefore may not have access to the same high productive foraging ground on consecutive trips. Exceptions to this seem to be Phoebastria immutabilis (Rothschild, 1893) and Phoebastria nigripes (Audubon, 1839) breeding in Hawaii, but both upwelling systems near colonies and the argument that these species can forage on temperate waters may represent a non-tropical foraging behaviour (Congdon et al., 2005).

According to Congdon et al. (2005), long trips build body reserves on parents, passed on to the chicks by lack of optimal self-provisioning during the early stages of a short trip cycle. When some threshold value is reached, adults attempt to maintain their own weight and satisfy chick requirements, but fail. Therefore, adults cannot obtain sufficient food for chick and self-provision during short trips and need to access sites of higher productivity on long trips (Sommerfeld and Hennicke, 2010; Ochi et al., 2016). Partners did not engage in long foraging trips at the same time following the coordinated trip changeover described by Congdon et al. (2005), Sommerfeld and Hennicke (2010) and Shoji et al. (2015). It might be that dual-foraging pattern depends on the partner's long trip (a pair-coordinated pattern) (Shoji et al., 2015) or even that birds engage in contact while at sea and thus long trips are triggered by the return of the mate from a long trip (Congdon et al., 2005).

This study shows longer foraging trips while brooding and rearing chicks than registered by Sommerfeld and Hennicke (2010) on Christmas Island, Le Corre et al. (2003) on Europa Island and Le Corre (personal communication) on WTTB on Seychelles (as shown in Table 4) and overall higher 
Table 4. Comparison of dual foraging strategy in seabirds and WTTB breeding of Fernando de Noronha.

\begin{tabular}{|c|c|c|c|c|}
\hline Species & Short Trips & Long Trips & Site & Reference \\
\hline Blue petrels & 1-3 days & 5-10 days & Mayes Island (Antartic) & $\begin{array}{c}\text { Chaurand and } \\
\text { Weimerskirch } 1994\end{array}$ \\
\hline $\begin{array}{l}\text { Wedge-tailed } \\
\text { shearwater }\end{array}$ & $1-4$ days & $6-10$ days & Heron Island (Australia) & Congdon et al. 2005 \\
\hline Red-tailed tropicbird & 3 hours & 57.4 hours & Christmas Island (Indian Ocean) & $\begin{array}{c}\text { Sommerfeld and } \\
\text { Hennicke } 2010\end{array}$ \\
\hline Manx shearwater & 1-3 days & 8-11 days & Skomer Island (UK) & Shoji et al. 2015 \\
\hline $\begin{array}{l}\text { Wedge-tailed } \\
\text { shearwater }\end{array}$ & 1-2 days & 12 days & Heron Island (Australia) & McDuie et al. 2015 \\
\hline $\begin{array}{l}\text { White-Tailed } \\
\text { tropicbird }\end{array}$ & 1 day & 4-11 days & FN Archipelago & This study \\
\hline
\end{tabular}

mean foraging range during short trips than Sommerfeld and Hennicke (2010), suggesting that the southwestern Atlantic oceanic environment around the breeding colony at Fernando de Noronha may show less prey availability than other tropical areas. It may be that WTTB in Fernando de Noronha use dual foraging strategies only during years of low prey availability (Granadeiro et al., 1998) and high productivity foraging grounds are accessed with long foraging trips in order to supplement food input to chicks beyond what is available in closer foraging areas (Congdon et al., 2005).

\subsection{Association with sub surface predators}

Although no in situ observation was conducted in order to determine association between tropicbirds and sub-surface predators in Fernando de Noronha, the direction of most of the foraging trips is highly contrasting with the known feeding locations of the Spinner Dolphin Stenella longirostris and Pantropical Spotted Dolphins Stenella attenuata dolphins that use the archipelago for resting and breeding (Silva-Júnior, 1996).

Therefore, WTTB breeding in Fernando de Noronha seem not to associate with dolphins in the Archipelago. In fact, none of the 26 trips (incomplete and complete) seemed to indicate that the birds choose to feed at the same locations used by dolphins, both at inshore and oceanic areas. This result corroborates with Spear and Ainley (2005) who found WTTB feeding both alone and using Tuna schools for feeding in the Pacific and Jaquemet et al. (2004), where the species used both feeding alone and pods of dolphins to maximize their feeding opportunities. Previous studies (Silva-Júnior, 1996) found that Spinner and Pantropical Spotted Dolphins of Fernando de Noronha feed mainly at oceanic areas such as Banco Sírius and Rochedo de São Pedro e São Paulo, located on west and north directions of Fernando de Noronha, respectively, while most of recorded trips of WTTB follow a southeast direction. Besides, the most abundant dolphins in the Archipelago, the Spinner Dolphins, feed at night, while our data was obtained mostly in trips during day time. This result, however, must be interpreted with caution since is based only in tracking data of tropicbirds and vessel-based and interviews information on Spinner Dolphins foraging sites.
The association between WTTB and Tuna schools is yet to be investigated. At sea observations are required in order to confirm that around Fernando de Noronha archipelago tropicbirds do not rely on sub-surface predators to feed.

\section{Acknowledgements}

This study was supported by Fundação de Amparo à Pesquisa do Estado de Alagoas (Fapeal) and Fundação Grupo Boticário de Proteção à Natureza. None of the funders had any input into the content of the manuscript or required their approval of the manuscript before submission. We would like to thank the staff of the Parque Nacional Marinho de Fernando de Noronha and the Capitania dos Portos de Pernambuco for logistical assistance, professors Ricardo Correa and Marcos Vital for statistical guidance.

\section{References}

ASHMOLE, N.P., 1971. Seabird ecology and the marine environment. Avian Biology, vol. 1, pp. 223-286.

AU, D.W. and PITMAN, R.L., 1989. Seabird relationships with tropical tuna and dolphins. In: J. BURGER, ed. Seabirds and other marine vertebrates. New York: Columbia University Press, pp. 174-212.

BALLANCE, L.T. and PITMAN, R.L., 1999. Foraging ecology of tropical seabirds. In: N.J. ADAMS and R.H. SLOTOW, eds. Proceeding of the 22nd International Congress, 16-22 August 1998, Durban, África do Sul. Johannesburg: Birdlife South Africa.

BALLANCE, L.T., PITMAN, R.L. and REILLY, S.B., 1997. Seabird community structure along a productivity gradient: Importance of competition and energetic constraint. Ecology, vol. 78, no. 5, pp. 1502-1518. http://dx.doi.org/10.1890/00129658(1997)078[1502:SCSAAP]2.0.CO;2.

BAYLIS, A.M.M., PAGE, B. and GOLDSWORTHY, S.D., 2008. Colony-specific foraging areas of lactating New Zealand fur seals. Marine Ecology Progress Series, vol. 361, pp. 279-290. http://dx.doi.org/10.3354/meps07258.

BONADONNA, F., LEA, M.A., DEHORTER, O. and GUINET, C., 2001. Foraging ground fidelity and route-choice tactics of a marine predator: the Antartic fur Seal Arctocephalus gazella. Marine Ecology Progress Series, vol. 223, pp. 287-297. http:// dx.doi.org/10.3354/meps223287. 
BRADSHAW, C.J.A., HINDELL, M.A., SUMNER, M.D. and MICHAEL, K.J., 2004. Loyalty pays: potential life history consequences of fidelity to marine foraging regions by southern elephant seal. Animal Behaviour, vol. 68, no. 6, pp. 1349-1360. http://dx.doi.org/10.1016/j.anbehav.2003.12.013.

BRASIL. Ministério do Meio Ambiente - MMA, 2014 [viewed 14 November 2016]. Portaria MMA $n^{\circ} 444$, de 17 de dezembro de 2014 [online]. Available from: http://www.icmbio.gov.br/ cepsul/images/stories/legislacao/Portaria/2014/p_mma_444_2014

CATRY, T., RAMOS, J.A., LE CORRE, M. and PHILLIPS, R.A., 2009. Movements, at-sea distribution and behaviour of a tropical pelagic seabird: the wedge-tailed shearwater in the western Indian Ocean. Marine Ecology Progress Series, vol. 391, pp. 231-242. http://dx.doi.org/10.3354/meps07717.

CHAURAND, T. and WEIMERSKIRCH, H., 1994. The regular alternation of short and long foraging trips in the blue petrel Halobaena caerulea: a previously undescribed strategy of food provisioning in a pelagic seabird. Journal of Animal Ecology, vol. 63, no. 2, pp. 275-282. http://dx.doi.org/10.2307/5546.

CONGDON, B.C., KROCKENBERGER, A.K. and SMITHERS, B.V., 2005. Dual-foraging and co-ordinated provisioning in a tropical Procellariiform, the wedge-tailed shearwater. Marine Ecology Progress Series, vol. 301, pp. 293-301. http://dx.doi. org/10.3354/meps301293.

DEARBORN, D.C., ANDERS, A.D. and FLINT, E.N., 2001. Trends in reproductive success of Hawaiian seabirds: is guild membership a good criterion for choosing indicator species? Biological Conservation, vol. 101, no. 1, pp. 97-103. http://dx.doi. org/10.1016/S0006-3207(01)00030-1.

DÜING, W., OSTAPOFF, F. and MERLE, J., 1980. Physical oceanography of the tropical Atlantic during GATE. Miami: University of Miami.

GRANADEIRO, J.P., NUNES, M., SILVA, M.C. and FURNESS, R.W., 1998. Flexible foraging strategies of Cory's shearwater, Calonectris diomedea, during the chick-rearing period. Animal Behaviour, vol. 56, no. 5, pp. 1169-1176. PMid:9819333. http:// dx.doi.org/10.1006/anbe.1998.0827.

HAMER, K.C., MONAGHAN, P., UTTLEY, J.D., WALTON, P. and BURNS, M.D., 1993. The influence of food supply on the breeding ecology of kittiwakes Rissa tridactyla in Shetland. The Ibis, vol. 13, pp. 255-263.

INSTITUTO BRASILEIRO DO MEIO AMBIENTE E DOS RECURSOS NATURAIS RENOVÁVEIS - IBAMA, 1990. plano de manejo do Parque Nacional Marinho de Fernando de Noronha. Brasília: FUNATURA.

JAQUEMET, S., LE CORRE, M. and WEIMERSKIRCH, H., 2004. Seabird cmmunity structure in a coastal tropical environment: importance of natural factors and fish aggregating devices (FAD). Marine Ecology Progress Series, vol. 268, pp. 281-292. http:// dx.doi.org/10.3354/meps268281.

KOTZERKA, J., HATCH, S.A. and GARTHE, S., 2011. Evidence for foraging-site fidelity and individual foraging behavior of pelagic cormorants rearing chicks in the Gulf of Alaska. The Condor, vol. 113, no. 1, pp. 80-88. http://dx.doi.org/10.1525/ cond.2011.090158.

LE CORRE, M., 2001. Breeding seasons of seabirds at Europa Island (southern Mozambique Channel) in relation to seasonal changes in the marine environment. Journal of Zoology, vol. 254, no. 2, pp. 239-249. http://dx.doi.org/10.1017/S0952836901000759.
LE CORRE, M., CHEREL, Y., LAGARDE, F., LORMÉE, H. and JOUVENTIN, P., 2003. Seasonal and inter-annual variation in the feeding ecology of a tropical oceanic seabird, the red-tailed tropicbird Phaethon rubricauda. Marine Ecology Progress Series, vol. 255, pp. 289-301. http://dx.doi.org/10.3354/meps255289.

LEAL, G.R., SERAFINI, P.P., SIMÃO-NETO, I., LADLE, R.J. and EFE, M.A., 2016. Breeding of White-tailed Tropicbirds (Phaethon lepturus) in the western South Atlantic. Brazilian Journal of Biology $=$ Revista Brasileira de Biologia, vol. 76, no. 3, pp. 559-567. http://dx.doi.org/10.1590/1519-6984.16514.

LONGHURST, A.R. and PAULY, D., 1987. Ecology of Tropical Oceans. San Diego: Academic Press.

MCDUIE, F., WEEKS, S.J., MILLER, M.G.R. and CONGDON, B.C., 2015. Breeding tropical shearwaters use distant foraging sites when self-provisioning. Marine Ornithology, vol. 43, pp. 123-129.

MOREIRA, J.C., 2009. Guia geológico de Fernando de Noronha. São Paulo: Nícia Guerreiro Edições.

NUNES, G.T., EFE, M.A., FREITAS, T.R.O. and BUGONI, L., 2017. Conservation genetics of threatened Red-billed Tropicbirds and White-tailed Tropicbirds in the soutwestern Atlantic Ocean. The Condor, vol. 119, no. 2, pp. 251-260. http://dx.doi.org/10.1650/ CONDOR-16-141.1.

OCHI, D., MATSUMOTO, K., OKA, N., DEGUCHI, T., SATO, K., SATOH, T.P., MUTO, F. and WATANUKI, Y., 2016. Dual foraging strategy and chick growth of Streaked Shearwater Calonectris leucomelas at two colonies in different oceanographic environments. Ornithological Science, vol. 15, no. 2, pp. 213-225. http://dx.doi.org/10.2326/osj.15.213

ORTA, J., 1992. Family Phaethontidae. In: J. DEL HOYO, A. ELLIOTT and J. SARGATAL, eds. Handbook of the birds of the world. Barcelona: Lynx Editions. vol. I. pp. 280-289. Ostrich to Ducks.

SCHAFFNER, F.C., 1990. Food provisioning by White-Tailed Tropicbirds: effects on the developmental pattern of chicks. Ecology, vol. 71, no. 1, pp. 375-390. http://dx.doi.org/10.2307/1940275.

SHOJI, A., ARIS-BROSOU, S., FAYET, A., PADGET, O., PERRINS, C. and GUILFORD, T., 2015. Dual foraging and pair coordination during chick provisioning by Manx shearwaters: empirical evidence supported by a simple model. The Journal of Experimental Biology, vol. 218, no. Pt 13, pp. 2116-2123. PMid:25964419. http://dx.doi.org/10.1242/jeb.120626.

SILVA-JÚNIOR, J. M., 1996. Aspectos do comportamento do Golfinho-rotador Stenella longirostris (Gray, 1828), no Arquipélago de Fernando de Noronha. 133 p. Recife: Universidade Federal de Pernambuco. Dissertação de Mestrado em Oceanografia.

SOMMERFELD, J. and HENNICKE, J., 2010. Comparison of trip duration, activity pattern and diving behaviour by Redtailed Tropicbirds (Phaethon rubricauda) during incubation anc chick-rearing. The Emu, vol. 110, no. 1, pp. 78-86. http://dx.doi. org/10.1071/MU09053.

SPEAR, L.B. and AINLEY, D.G., 2005. At-sea behaviour and habitat use by tropicbirds in the eastern Pacific. The Ibis, vol. 147, no. 2, pp. 391-407. http://dx.doi.org/10.1111/j.1474919x.2005.00418.x.

STONEHOUSE, B., 1962. The tropicbirds (Genus Phaethon) of Ascension Island. The Ibis, vol. 103, pp. 124-161.

THIERS, L., LOUZAO, M., RIDOUX, V., LE CORRE, M., JAQUEMET, S. and WEIMERSKIRCH, H., 2014. Combining 
methods to describe important marine habitats for top predators: Application to identify biological hotspots in tropical waters. PLoS One, vol. 9, no. 12, pp. e115057. PMid:25494047. http:// dx.doi.org/10.1371/journal.pone.0115057.

WEIMERSKIRCH, H., 1998. How can a pelagic seabird provision its chick when relying on a distant food resource? Cyclic attendance at the colony, foraging decision and body condition in sooty shearwaters. Journal of Animal Ecology, vol. 67, no. 1, pp. 99-109. http://dx.doi.org/10.1046/j.1365-2656.1998.00180.x.

WEIMERSKIRCH, H., 2007. Are seabirds foraging for unpredictable resources? Deep-sea Research Part II, Topical
Studies in Oceanography, vol. 54, no. 3-4, pp. 211-223. http:// dx.doi.org/10.1016/j.dsr2.2006.11.013.

WEIMERSKIRCH, H., SALAMOLARD, M., SARRAZANI, F. and JOUVENTIN, P., 1993. Foraging strategy of wandering albatrosses through the breeding season: A study using satellite telemetry. The Auk, vol. 110, no. 2, pp. 325-342.

WILSON, R.P., PÜTZ, K., PETERS, G., CULIK, B., SCOLARO, J.A., CHARRASSIN, J.B. and COUDERT, Y.R., 1997. Long-term attachment of transmitting and recording devices to penguins and other seabirds. Wildlife Society Bulletin, vol. 25, no. 1, pp. 101-106. 